\title{
Penggunaan Media Komunikasi Organisasi di Yayasan Sayap Ibu Daerah Istimewa Yogyakarta dan Kopilimo Café \& Homestay
}

\author{
MC Ninik Sri Rejeki ${ }^{1}$, Sherly Hindra Negoro ${ }^{2}$ \\ Universitas Atma Jaya Yogyakarta, Jalan Babarsari No. 6 \\ Email: sherly.hindra@uajy.ac.id ${ }^{2}$
}

Received: December 15, 2021; Revised:-; Accepted for Publication: January 5, 2022 ; Published: January 5, 2022

\begin{abstract}
Abstrak--Sebuah organisasi penting untuk memahami komunikasi organisasi. Dengan pemahaman yang baik dari para aktor pengelola organisasi, maka akan tercapai praktek komunikasi organisasi yang berkualitas. Salah satu praktek komunikasi organisasi adalah penggunaan media komunikasi organisasi. Yayasan Sayap Ibu DIY (YSI) dan Kopilimo Café \& Homestay belum memiliki panduan penggunaan media komunikasi organisasi. Permasalahannya adalah tidak terdistribusikannya informasi yang penting dan bermanfaat, lemahnya pemahaman akan konsep komunikasi organisasi, dan lemahnya fungsi koordinasi. Pengabdian kepada masyarakat ini bertujuan untuk memberikan pendampingan bagi YSI dan Kopilimo Café \& Homestay dalam menyusun panduan penggunaan media komunikasi organisasi.

Landasan teoritik yang digunakan dalam penyusunan panduan adalah komunikasi organisasi, mencakup konsep komunikasi organisasi dan media komunikasi organisasi, serta pemanfataannya. Metode pelaksanaan pendampingan berupa ceramah, diskusi, dan workshop.

Target pendampingan sebanyak tujuh kali pertemuan dengan luaran pengabdian berupa panduan penggunaan media komunikasi organisasi. Panduan memuat jenis media, konsep, dan tata cara penggunaan, serta petunjuk teknis dalam menggunakan setiap jenis media. Kesimpulan dari kegiatan pengabdian kepada masyarakat ini adalah bahwa efektifitas komunikasi organisasi harus ditunjang oleh tersedianya panduan penggunaan media komunikasi organisasi yang terrencana. Untuk itu diperlukan pendampingan dari tim pengabdi yang memiliki kompetensi di bidang komunikasi organisasi.
\end{abstract}

Kata Kunci - Komunikasi Organisasi, Media Komunikasi Organisasi, Panduan Penggunaan Media

\section{PENDAhUluan}

Organisasi terdiri atas dua unsur penting, yaitu teknis dan manusia [1]. Oleh sebab itu, sebuah organisasi penting untuk memahami konsep komunikasi organisasi. Seperti yang tertuang dalam riset Oktaviani et al., yang menemukan bahwa peran komunikasi organisasi adalah untuk mewujudkan harapan atau tujuan organisasi, mediator pengurus dan anggota, produktivitas dan mutu kualitas kinerja, pemecahan masalah, kegiatan internal dan eksternal, serta kelancaran operasional [2]. Komunikasi organisasi serta kepuasan kerja berkontribusi dalam peningkatan kinerja karyawan [3]. Riset yang dilakukan oleh Cahyanto menyebutkan bahwa komunikasi organisasi dapat meningkatkan keupasan kerja karyawannya [4].

Komunikasi organisasi secara konseptual memiliki pengertian sebagai kinerja dan penafsiran pesan di antara unit-unit komunikasi dalam sebuah organisasi [5]. Berdasarkan pengertian tersebut, implikasi dari komunikasi organisasi pada dasarnya terkait dengan penyampaian pesan di antara unit-unit dalam sebuah organisasi guna menjalankan praktek-praktek organisasi. Hal tersebut mencakup sosialisasi, pengambilan keputusan, manajemen konflik, teknologi, emosi, dan diversitas.

Sebuah organisasi penting untuk memahami komunikasi organisasi. Dengan adanya pemahaman yang baik akan menuntun pada praktek-praktek komunikasi organisasi yang baik pula, sehingga akan terjadi sistem organisasi yang berkualitas. Demikian pula halnya dengan Yayasan Sayap Ibu (YSI) sebagai mitra pengabdian kepada masyarakat yang akan dilaksanakan oleh tim dari Universitas Atma Jaya Yogyakarta.

YSI merupakan organisasi non-pemerintah atau lembaga swadaya masyarakat yang bergerak dalam penyantunan anak terlantar secara menyeluruh, terpadu, dan berkelanjutan. Yayasan ini berdiri pada tahun 1955, hingga sekarang sudah memiliki empat cabang di bawah struktur YSI Pusat yang berkedudukan di Jakarta. Cabang-cabang itu adalah YSI Cabang Jakarta, YSI Cabang Daerah Istimewa Yogyakarta (D.I.Y), YSI Cabang Banten, dan YSI Cabang Surabaya. Pengabdian kepada masyakarat ini akan dilaksanakan di YSI Cabang D.I.Y.

YSI Cabang D.I.Y. dalam rencana strategis (Renstra) 2015-2019 menetapkan bahwa komunikasi organisasi di lembaga tersebut perlu dikelola efektif dengan membangun media komunikasi. Media komunikasi perlu dibangun dengan memperhatikan arah aliran informasi formal dalam organisasi. Arah aliran informasi yang berbeda memerlukan media komunikasi yang berbeda pula. Adapun indikator efektivitas akan dilihat dari terwujdunya komunikasi aktif antara pengurus dan karyawan, serta terdistribusikannya informasi yang perlu diketahui oleh sumberdaya manusia YSI Cabang D.IY. Strategi tersebut bertolak dari kelemahan dalam konteks komunikasi organisasi di YSI sebagai berikut:

(1) Tidak terdistribusikannya informasi organisasi yang bermanfaat bagi pengembangan organisasi.

(2) Lemahnya pemahaman tentang manajemen dan komunikasi organisasi.

(3) Lemahnya fungsi koordinasi.

Tim pengabdian juga melaksanakan kegiatan pengabdian kepada masyarakat di Kopilimo Homestay. Kopilimo Homestay merupakan organisasi bergerak di bidang hospitality. Sebagai destinasi hunian yang baru, Kopilimo perlu meninjau dan meningkatkan komunikasi yang terjadi pada organisasi tersebut. Penggunaan media komunikasi yang digunakan di dalam internal organisasi serta berkomunikasi dengan pihak eksternal perlu dipahami. Hal tersebut dikarenakan berbagai pilihan media komunikasi dapat memberikan kemanfaatan, kelebihan, dan kelemahan yang berbeda. 
Secara teoritik, aliran informasi formal dalam organisasi terdiri dari empat arah, yaitu komunikasi ke bawah; komunikasi ke atas; komunikasi horizontal; dan komunikasi lintas saluran. Dalam komunikasi ke bawah, informasi mengalir dari seseorang yang otoritasnya lebih tinggi kepada orang lain yang otoritasnya lebih rendah. Sebaliknya, dalam komunikasi ke atas, informasi mengalir dari seseorang dengan otoritas lebih rendah ke seseorang yang otoritasnya lebih tinggi. Sementara itu, dalam komunikasi horizontal, informasi bergerak di antara orang-orang dengan dengan jabatan yang memiliki otoritas setingkat, sedangkan dalam komunikasi lintas saluran, informasi bergerak di antara orang-orang dan jabatan-jabatan yang lintas satu dengan lainnya, serta menempati bagian fungsional yang berbeda [5]

Kualitas kinerja komunikasi organisasi ditentukan oleh perencanaan media dalam berbagai konteks aliran informasi organisasi. Perencanaan media adalah proses pengambilan keputusan yang terkait dengan seleksi dan penentuan media. Perencanaan ini dituangkan dalam bentuk panduan komunikasi organisasi.

Media komunikasi pada dasarnya merupakan sarana untuk menyampaikan pesan. West \& Turner menyatakan bahwa ketika pilihan-pilihan akan saluran komunikasi meningkat, maka jumlah pesan yang dikirim dan diterima, serta kecepatan pengiriman pesan akan meningkat pula [6]. Hal ini dapat diartikan ketika banyak alternatif media komunikasi organisasi disediakan, maka akan memungkinkan makin banyaknya pesan yang dapat dikirim dan diterima, serta memungkinkan cepatnya pengiriman pesan.

Media komunikasi dalam konteks ini tidak hanya terbatas pada media konvensional, namun juga mencakup media baru. Contoh dari media konvensional adalah brosur dan leaflet. Sedangkan, media baru dapat berupa media sosial. Media baru membuat organisasi mampu menyelesaikan tujuan dalam berbagai cara yang belum pernah dicapai sebelumnya [6]. Dari hasil penelitian mengenai aliran komunikasi organisasi, diperoleh bahwa media komunikasi yang digunakan untuk melakukan komunikasi internal dapat berupa media sosial dan aplikasi yang hanya diakses secara internal saja. [7]. Media komunikasi internal dapat dipilih sesuai dengan kemudahan penggunaan terutama diakses menggunakan gadget. Di sisi lain, penggunaan aplikasi yang dapat diakses oleh internal dapat digunakan untuk memonitor dan mengevaluasi kerja karyawan [7].

\section{MEtode Pengabdian}

Tim pengabdi telah melakukan pertemuan dengan pengurus Yayasan Sayap Ibu cabang Yogyakarta serta pimpinan Kopilimo café \& homestay sebagai lokasi pengabdian. Pertemuan ini bertujuan untuk menggali persoalan organisasi. Dari penggalian informasi ini, tim pengabdi melakukan perencanaan kegiatan pengabdian.

Kegiatan pengabdian dibagi menjadi tiga bentuk, yakni pemaparan materi/ceramah, workshop, serta menghasilkan luaran pengabdian dalam bentuk panduan penggunaan media komunikasi organisasi untuk masing-masing mitra. Kegiatan tersebut secara rinci diuraikan sebagai berikut:

1. Pemaparan materi/ceramah
Materi disampaikan oleh tim pengabdi dengan menggunakan referensi yang berfokus pada media komunikasi organisasi. Materi disampaikan dengan menggunakan power point dan membagikan hand out materi kepada peserta. Selain itu, tim pengabdi juga membuka sesi diskusi dengan peserta.

2. Workshop

Workshop dalam kegiatan ini dilakukan dengan membagi peserta ke dalam kelompok kecil sesuai divisi. Peserta diminta melakukan identifikasi sesuai topik yang disampaikan. Tim pengabdi menyiapkan kertas plano serta spidol yang dibagikan kepada peserta. Setelah peserta mendiskusikan ke dalam kelompok kecil, peserta memaparkan hasil diskusi. Dari hasil diskusi tersebut, tim pengabdi mencatat dan menjadikan referensi untuk menyusun panduan penggunaan media komunikasi organisasi.

3. Panduan/pedoman penggunaan media komunikasi organisasi.

Di akhir pengabdian, tim pengabdi menyusun panduan penggunaan media komunikasi organisasi dalam bentuk cetak dan online. Panduan/pedoman ini selanjutnya diberikan kepada dua institusi lokasi pengabdi sebagai acuan pengelolaan organisasi masing-masing. Pedoman di dalam organisasi berupa prosedur komunikasi. Prosedur komunikasi perlu distandarisasi agar menimbulkan pemahaman serta tindakan komunikasi yang sama [8]. Media atau saluran komunikasi memiliki andil yang penting untuk keberlangsungan komunikasi . Oleh karena itu, internal organisasi perlu memiliki keterampilan berkomunikasi dan wawasan mengenai saluran/media komunikasi untuk berkomunikasi dengan receiver [9]. Dalam pedoman tersebut tim pengabdian memberikan gambaran mengenai karakteristik dari media konvensional dan media sosial. Media konvensional ini memiliki keakuratan dan mutakhir [9]. Sedangkan, media sosial memiliki beberapa karakter, yaitu pesan tidak hanya disampaikan oleh satu orang, pesan bersifat bebas tanpa ada gatekeeper, penyampaian pesan cepat, penerima pesan menentukan waktu interaksi [10].

\section{HASIL DAN PEMBAHASAN}

\section{Kegiatan Pengabdian di Yayasan Sayap Ibu Cabang DIY}

Kegiatan pengabdian di Yayasan Sayap Ibu Cabang DIY dilaksanakan bertempat di aula pertemuan Jl. Rajawali, Pringwulung Yogyakarta. Peserta yang hadir pada kegiatan adalah perwakilan karyawan di kantor Pringwulung dan karyawan yang mengelola Panti. Tim pengabdi melakukan kegiatan pengabdian sebanyak empat kali.

Pertama, tim pengabdi memberikan materi mengenai pemahaman komunikasi organisasi. Tujuan pemberian materi ini adalah memberikan gambaran konsep dasar komunikasi organisasi kepada karyawan. Konten materi yang diberikan kepada karyawan berupa pengertian organisasi, unsur-unsur yang ada dalam organisasi, hubungan antara 
organisasi dan komunikasi, komunikasi organisasi serta komponen dalam komunikasi organisasi.

Materi diberikan dengan penyederhanaan konsep serta contoh yang riil yang biasa ditemukan dalam keseharian. Metode yang diterapkan adalah ceramah dan diskusi tanya jawab. Kegiatan dilaksanakan pada Sabtu, 28 Juni 2018 dan dihadiri 29 peserta.

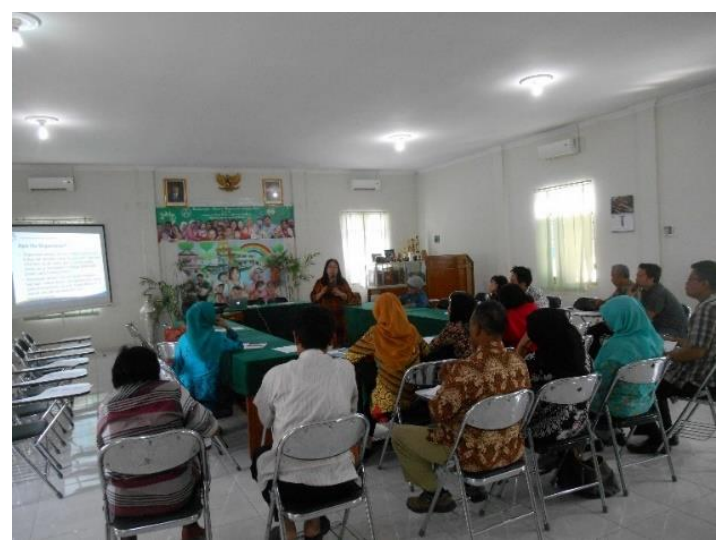

Gambar1. Pelaksanaan pengabdian pertama

Kedua, tim pengabdi mengerucutkan materi pengabdian mengenai media komunikasi organisasi. Media komunikasi yang dapat digunakan oleh organisasi beragam diantara pilihan media yang ada. Namun, hal yang perlu menjadi penekanan bahwa efektivitas media komunikasi organisasi berbeda-beda tergantung kebutuhan organisasi. Oleh sebab itu, dalam berkomunikasi secara internal, organisasi perlu menentukan media yang tepat digunakan sesuai dengan karakter anggota organisasi. Metode yang diterapkan adalah ceramah dan diskusi tanya jawab. Kegiatan dilaksanakan pada Senin, 5 Agustus 2018 dan dihadiri 13 peserta

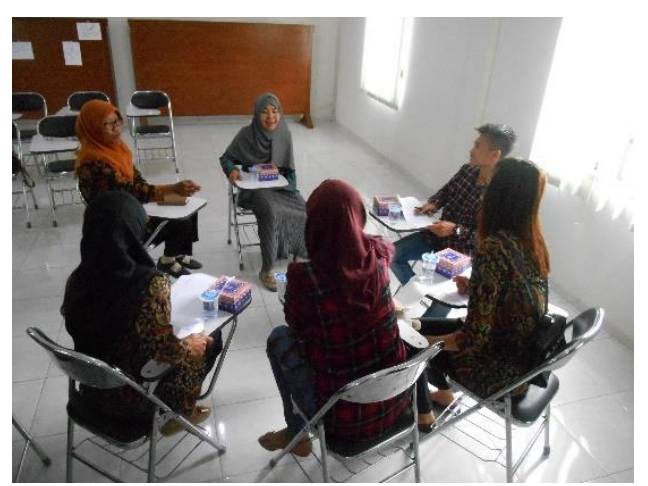

Gambar 2. Dokumentasi kegiatan pertemuan kedua di YSI cabang DIY

Ketiga, tim pengabdi menggunakan metode workshop guna menggali akar masalah penggunaan media yang digunakan oleh YSI. Peserta dibagi menjadi beberapa kelompok. Kelompok dibekali spidol dan kertas plano dan menuliskan hasil diskusi berdasarkan pertanyaan yang disampaikan di awal. Setelah peserta melakukan diskusi, tim pengabdi memberikan kesempatan kepada perwakilan masing-masing kelompok untuk menyampaikan hasil diskusi. Tim pengabdi mencatat hasil diskusi. Setelah pemaparan selesai, tim pengabdi menunjukkan hasil rangkuman diskusi kepada peserta. Dari hasil tersebut, tim pengabdi memberikan rekomendasi atas persoalan yang terjadi. Hasil pemetaan masalah, kelebihan dan kekurangan media komunikasi, rekomendasi ini menjadi acuan bagi tim pengabdi menyusun pedoman penggunaan media komunikasi yang menjadi output dari pengabdian ini. Kegiatan dilaksanakan pada Sabtu, 1 September 2018 dan dihadiri 28 peserta.

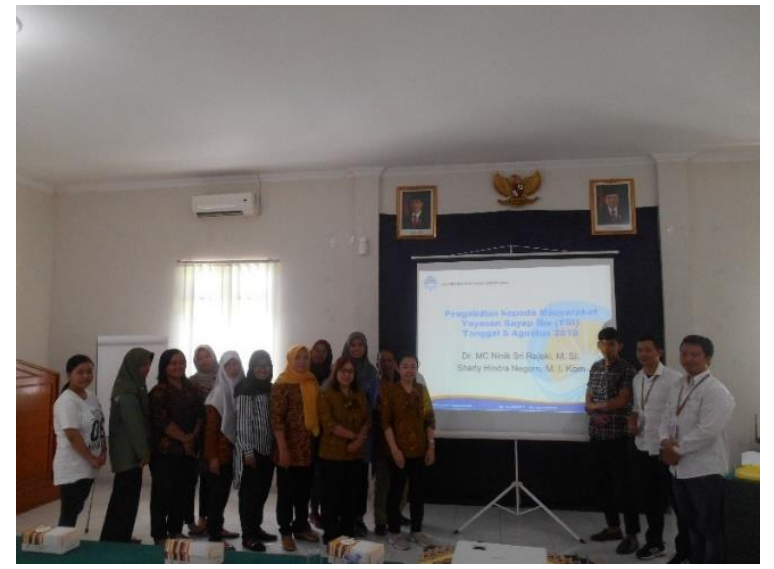

Gambar 3. Dokumentasi kegiatan pertemuan ketiga di YSI cabang DIY

Keempat, tim pengabdi menutup pengabdian di YSI dengan materi pertemuan terakhir mengenai membangun relasi dengan pihak internal dengan metode workshop. Kegiatan dilaksanakan pada Kamis, 19 Desember 2019 dan dihadiri 27 peserta. Peserta diberikan pertanyaan reflektif yang dijawab sebagai awalan diskusi. Peserta diberi pertanyaan mengenai nilai-nilai yang perlu dijunjung pada relasi internal, baik antara pengurus dengan karyawan maupun diantara karyawan. Pertanyaan tersebut meliputi, prinsip melayani, bijaksana dan perhatian, empati, hati-hati di dalam berbicara, serta memikirkan perasaan orang lain.

Pengenalan atas prinsip relasi internal ini perlu diberikan kepada peserta agar di dalam relasi yang diterapkan organisasi memegang teguh pada lima hal tersebut. Prinsip tersebut dapat terwujud apabila komunikasi internal dilakukan dengan baik. Hal yang menjadi kunci keberhasilan komunikasi yang baik apabila melakukan beberapa hal:

a. Pesan yang tepat akan menentukan pemilihan media yang relevan yang digunakan oleh anggota organisasi

b. Organisasi sebaiknya memiliki preferensi penggunaan media komunikasi yang beragam yang disesuaikan dengan kebutuhan bentuk pesan

c. Komunikasi tatap muka yang sehari-hari dilakukan oleh organisasi menjadi pilihan yang baik dengan menggunakan pesan yang jelas dan sederhana

d. Forum rapat merupakan komunikasi yang ruang lingkupnya adalah komunikasi kelompok 


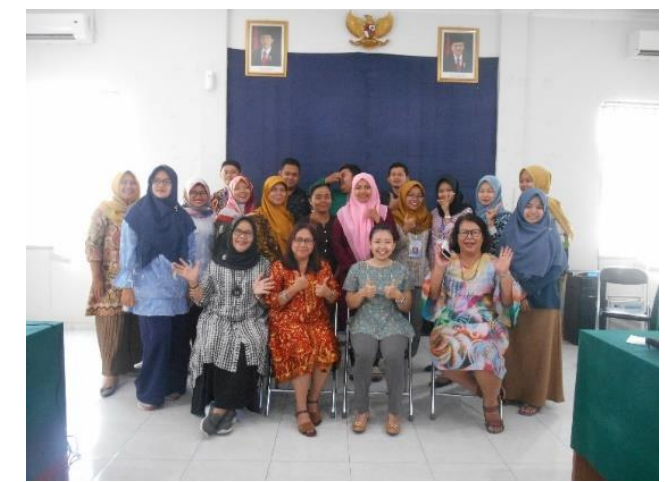

Gambar 4. Dokumentasi kegiatan pertemuan keempat di YSI cabang DIY

\section{Kegiatan Pengabdian di Kopilimo Café \& Homestay}

Kegiatan pengabdian di Kopilimo Café \& Homestay dilakukan oleh tim pengabdi sebanyak 3 kali. Kegiatan ini bertempat di Kopilimo dan dihadiri oleh karyawan. Kegiatan pengabdian ini tidak jauh berbeda dengan kegiatan yang dilakukan di YSI Cabang D.I.Y. Luaran dari pengabdian ini adalah pedoman penggunaan media komunikasi organisasi yang dapat menjadi acuan bagi pihak internal mengelola komunikasi internal dan eksternal dengan media komunikasi yang tepat. Kegiatan pendampingan ini dilaksanakan sebanyak tiga kali.

Pertama, kegiatan pertama yang dilakukan tim pengabdi adalah pemberian materi mengenai pemahaman dasar komunikasi organisasi. Materi ini diberikan kepada karyawan Kopilimo café \& Homestay dengan tujuan memberikan gambaran awal bagi karyawan. Materi yang diberikan meliputi pengertian organisasi, unsur-unsur yang ada dalam organisasi, hubungan antara organisasi dan komunikasi, komunikasi organisasi serta komponen dalam komunikasi organisasi. Metode yang diterapkan adalah ceramah dan diskusi tanya jawab. Kegiatan dilaksanakan pada Jumat, 3 Mei 2019 dan dihadiri 19 peserta.

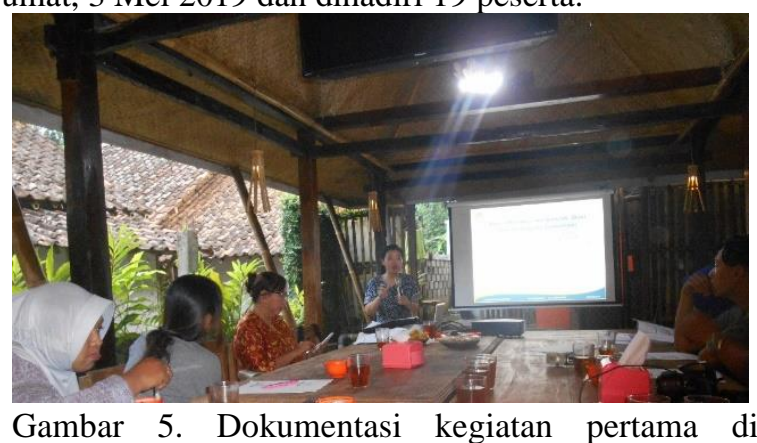
Kopilimo

Kedua, tim pengabdi memberikan materi pengabdian mengenai media komunikasi organisasi. Organisasi dihadapkan pada berbagai media komunikasi yang digunakan oleh organisasi. Namun, terkadang penggunaannya menjadi tidak tepat. Komunikasi yang dilakukan di dalam organisasi perlu menentukan media yang tepat digunakan sesuai dengan karakter anggota organisasi. Metode yang diterapkan adalah ceramah dan diskusi tanya jawab. Selain itu, peserta diminta menyampaikan mengenai media-media yang digunakan oleh
Kopilimo Café \& Homestay serta penggunaan yang selama ini digunakan. Kegiatan dilaksanakan pada Jumat, 28 Juni 2019 dan dihadiri 10 peserta.

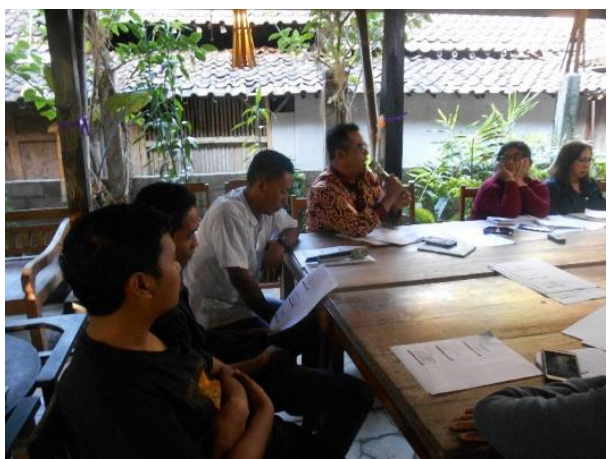

Gambar 6. Dokumentasi kegiatan kedua di Kopilimo

Ketiga, pada pertemuan ini, tim pengabdi menggunakan metode workshop untuk menggali permasalahan mengenai penggunaan media yang digunakan di Kopilimo Café \& Homestay. Peserta dibagi menjadi beberapa kelompok. Kelompok dibekali spidol dan kertas plano dan menuliskan hasil diskusi berdasarkan pertanyaan yang disampaikan di awal. Setelah peserta melakukan diskusi, tim pengabdi memberikan kesempatan kepada perwakilan masing-masing kelompok untuk menyampaikan hasil diskusi. Setelah pemaparan selesai, tim pengabdi merangkum dengan membuat notulensi hasil diskusi yang telah dilakukan peserta. Dari hasil tersebut, tim pengabdi memberikan rekomendasi atas persoalan yang terjadi.

Hasil dari diskusi ini menjadi acuan bagi tim pengabdi untuk menyusun pedoman penggunaan media komunikasi. Pedoman ini menjadi luaran dari pengabdian. Kegiatan dilaksanakan pada Jumat, 8 November 2019 dan dihadiri 20 peserta.

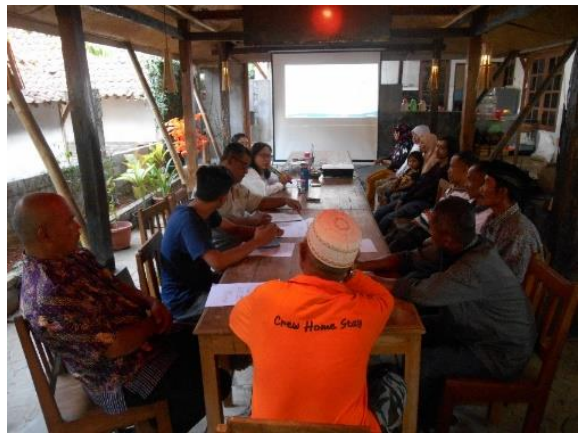

Gambar 7. Dokumentasi kegiatan ketiga di Kopilimo

\section{KESIMPULAN}

Berdasarkan kegiatan pengabdian yang dilakukan oleh tim pengabdian, dapat disimpulkan sebagai berikut:

1. Pemahaman akan komunikasi organisasi penting bagi pengurus dan anggota organisasi guna efektivitas aliran informasi untuk menunjang kegiatan organisasi. Efektivitas ini perlu ditunjang dengan panduan penggunaan media komunikasi yang terrencana. 
2. Perencanaan panduan penggunaan media komunikasi organisasi perlu pendampingan dari tim yang memiliki kompetensi di bidang komunikasi organisasi.

3. Penyuluhan dan pendampingan dilakukan tujuh kali di setiap organisasi, namun karena kesibukan mitra pengabdian maka target tersebut tidak terlaksana.

4. Metode workshop sesuai dalam need assesment, sementara ceramah dan diskusi untuk memberikan kompetensi kognitif.

Tim pengabdi memiliki harapan untuk kegiatan pengabdian yang akan datang. Penyuluhan tentang komunikasi organisasi dan pendampingan perencanaan media seyogyanya diikuti oleh semua pengurus, tidak hanya anggota organisasi di tingkat karyawan yang tidak punya kewenangan dalam pengambilan keputusan. Pengurus inti perlu memiliki pemahaman dan keterampilan dalam menyusun panduan media komunikasi organisasi.

\section{UCAPAN TERIMA KASIH}

Tim pengabdi mengucapkan terima kasih untuk kedua organisasi tempat pelaksanaan pengabdian, yaitu Yayasan Sayap Ibu Cabang DIY serta Kopilimo Café \& Homestay. Apresiasi kami ucapkan kepada pengurus serta karyawan yang telah terlibat dalam kegiatan ini.

\section{DAFTAR PUSTAKA}

[1] A. K. Batubara, "Aliran Informasi," Jurnal Iqra, vol. 10, no. 1, pp. 70-91, May 2016.

[2] O. : Oktaviani, M. Katuuk, N. Mewengkang, and E. R. Kalesaran, "PERAN KOMUNIKASI ORGANISASI DALAM MENINGKATKAN EKSISTENSI SANGGAR SENI VOX ANGELICA," 2016.

[3] L. Paramita, V. P. K. Lengkong, and G. M. Sendow, "THE EFFECT OF ORGANIZATION COMMUNICATION AND WORK STRESS TO WORK SATISFACTION AND THE IMPACT TO EMPLOYEE PERFORMANCE AT PERUM BULOG DIVRE SULUT," 2016.

[4] B. D. P. Cahyanto and I. W. M. Utama, "Komor \& Lingkungan Kerja," Manajemen Unud, vol. 5, no. 5, pp. 3248-3273, 2016.

[5] R. W. PACE and D. F. FAULES, Komunikasi Organisasi: Strategi Meningkatkan Kinerja Perusahaan. Bandung: Rosda, 2006.

[6] R. West and H. L. Turner, Pengantar Teori Komunikasi: Analisis dan Aplikasi. Jakarta: Salemba Humanika, 2008.

[7] B. Suswanto, "Aliran Informasi," Media kom, vol. 6, no. 2, pp. 1-15, 2016.

[8] B. W. Utami, M. Molo, and E. Widiyanti, "Kelembagaan \& Aliran Informasi," J-SEP, vol. 5, no. 3, pp. 45-53, 2011.

[9] I. Ruyadi, Y. Winoto, and N. Komariah, "MEDIA KOMUNIKASI DAN INFORMASI DALAM

\section{MENUNJANGKEGIATAN PENYULUHAN} PERTANIAN," Jurnal Kajian Informasi \& Perpustakaan, vol. 5, no. 1, pp. 37-50, 2017.

[10] O. : Eribka, R. David, M. Sondakh, and S. Harilama, "Pengaruh Konten Vlog dalam Youtube terhadap Pembentukan Sikap Mahasiswa Ilmu Komunikasi Fakultas Ilmu Sosial dan Politik Universitas Sam Ratulangi," 2017.

\section{PENULIS}

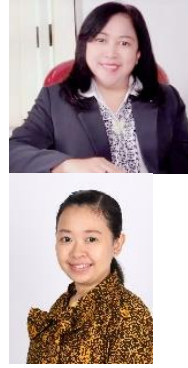

MC Ninik Sri Rejeki, prodi Ilmu Komunikasi, Fakultas Ilmu Sosial dan Ilmu Politik, Universitas Atma Jaya Yogyakarta.

Sherly Hindra Negoro, prodi Ilmu Komunikasi, Fakultas Ilmu Sosial dan Ilmu Politik, Universitas Atma Jaya Yogyakarta. 